\title{
APLIKASI ETIKA TASAWUF AL-GHAZALI DALAM MEWUJUDKAN GOOD GOVERNANCEDI INDONESIA
}

\author{
Oleh. Agus Iswanto*
}

\section{Abstract}

This article tries to exspose that apllication of tasawuf ethics may be done to actualize Good Governance in Indonesia. The first, I give some argument why I choose tasawuf and Ghazali as a focus in this study. Tasawuf as an Islamic tradition and capacity of Ghazali are two arguments which can be used. Contextualisation of social live of Ghazali can be examined why I choose him. There are three concept from his thought about tasawuf ethic: zuhd, teleologis ethic, and ummahât al-fadhâil. These concepts can be done to practice in reforming Indonesian Good Governance.

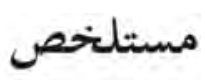

تسعى المقالة الحالية إلى التدليل على أن تطبيق أخلاقيات التصوف يمكنه أن يفعّل نظام الحكم الجيد في إندو نيسيا .ففي المقام الأول، تكشف المقالة عن السر في اختيار التصوف لدى الغزالي كموضوع للدراسة في هذا البحال؛ حيث يشكل كل من التصوف كتقليد إسلامي والأهلية التي يتمتع هـا الغزالي مقولتين يعتد بما . ومن جهة أخرى يمكننا إلقاء الضوء على السياق المختمعي إبان حياة الغزالي، ذلك السياق الذي يوضح أكثر سبب اختياره كموضوع للبحث .ثمة ثلاثة مفاهيم رئيسة للى الغزالي المتصوف يمكن الحديث عنها في إطار تطبيق إصلاححات النظام الإداري العام الإندونيسي؛ إذا الزهد، الأخهلاق الدينية، وأمهات الفضائل.

Keywords: tasawuf, kepekaan sosial, kesadaran ilabiyah.

Mahasiswa Program Islamic Research Magister Studi Islam (MSI) UII Yogyakarta.. Pembaca dalam bidang Islamic Studies. Aktif dalam Lembaga Studi Pesantren dan Masyarakat (eLSipem) Yogyakarta. Email: freethinker_jogja@yahoo.co.id 


\section{A. Pendahuluan}

Sampai hari ini musibah alam dan sosial masih berlanjut. Ingatan bangsa ini masih segar dengan musibah tsunami yang menenggelamkan Aceh, gempa bumi yang meluluhlantakan Yogyakarta, lumpur lapindo di Sidoarjo, disusul dengan gempa bumi di pelbagai belahan bumi pertiwi bangsa Indonesia. Belum lagi ancaman flu burung, maut yang seakan begitu dekat, tidak ada tempat aman lagi, kecelakaan baik di darat, laut dan udara seakan sepakat untuk, karena "alam" marah dengan manusia, serta musibah banjir, membuat bangsa ini semakin pesimis dengan upaya pemerintah untuk mengatasinya di waktu dekat. Di tengah terpaan musibah alam dan sosial, rakyat masih dibebani dengan serangkaian berita dan perilaku politik yang tidak jelas parameter kerjanya.

Kaburnya standar dan komitmen moral, diperparah lagi dengan lemahnya penegakan hukum, bahkan hukuman diperlakukan diskriminatif terhadap pelaku korupsi. Ada beberapa pejabat tinggi yang oleh masyarakat diyakini korup, tetapi dilindungi, sementara ada penjahat kelas teri mendapat hukuman berat. Hal ini akan mengaburkan batas halal-haram, baik-buruk, salah-benar, dan memperlemah wibawa pemerintah serta hukum. Lebih jauh lagi, kondisi demikian tidak saja memperbusuk budaya birokrasi, tetapi juga merusak perilaku masyarakat dan bangunan budaya yang sehat.

Apalagi di pelbagai media beredar rumor bahwa sebagian anggota DPR terlibat suap setiap ada agenda perumusan Rencana Undang-Undang (RUU) ${ }^{1}$. Hal ini tentu membuat citra dan kualitas politisi rapuh moralnya. Dengan demikian parameter atau tolok ukur etika dalam kehidupan sosial, birokrasi dan politik menjadi kabur, kelabu dan remang-remang, bahkan mungkin tidak tampak. Oleh karena itu, wajar dan logis apabila terdapat kritik bahwa parpol gagal dalam mencetak dan melahirkan para politisi bangsa yang tangguh dan bermoral. Yang ada adalah "politisi opportunistik."

Kemarahan masyarakat kian bertambah ketika melihat para tokoh agama dan intelektual kampus telah menjelma dan bermetamorfosis menjadi aktor politik, lalu terbawa arus, yang kemudian mengaburkan komitmen moral-intelektualnya.

Lalu siapa yang harus dan patut disalahkan? Jika agama saja tidak mampu menyadarkan kepekaan sosial atas dasar kesadaran Ilâbiyah, lalu kepada apa atau siapa lagi bangsa ini berharap? Agama dianggap telah gagal melakukan transformasi

1 Komarudin Hidayat, "Menertawakan Kegtiran Hidup," dalam Kompas, 21 April 2007. 
nilai-nilai humanis-liberatif, atau dalam bahasa al-Qur'an, amar ma'rûf. Indikatornya adalah merajalelanya tokoh-tokoh, cendekiawan, ulama, dan pemimpin-pemimpin Islam yang larut dalam gemerlap dan gagap gempita perebutan kekuasaan dan kekayaan, tanpa perduli dengan hak-hak rakyat bawah. ${ }^{2}$ Bahkan tidak lebih dari itu, dengan lantang mereka berkata dan maju atas nama rakyat, atau atas nama kepentingan bersama. Teori telah mati. Mungkin itu yang bisa dikatakan untuk menggambarkan "kemandulan" para tokoh cendekiawan dan ulama. Islam hanya berhenti pada batas minimal. Kalau sudah begitu, maka benar apa yang dikatakan Karl Marx (1818-1883) bahwa agama adalah candu masyarakat, atau seperti juga yang diproklamasikan oleh Friedrich Nietzsce (1844-1900) bahwa 'Tuhan telah mati'.

Namun, terlalu agak berlebihan jika kita harus menyalahkan pada agama. Sebab sejatinya agama (khususnya agama-agama samawr) mengantarkan manusia pada jalan kebenaran, jalan menuju dzât Ilâhiyah yang transenden. Akan tetapi, begitu agama sampai ke tangan manusia, saat itu pula agama menjadi sebuah budaya, bahkan cenderung menjadi ideologi penganut ajarannya. ${ }^{3}$ Di sini konsepsi manusia menjadi sangat berpengaruh terhadap pemahaman ajaran. Pemahaman ajaran ini selanjutnya diwujudkan dalam tingkah laku kehidupan sehari-hari. Sebuah konsepsi mungkin saja benar pada masa kemunculannya, tetapi kemudian menjadi tidak cocok untuk masa sekarang. Ketidakcocokan konsepsi dengan kenyataan masalah yang dihadapi tentu akan mengakibatkan hilangnya kekuatan konsepsi itu dalam membaca masalah. Begitu pula, sebuah konsepsi terhadap ajaran agama tidak selamanya akan sesuai dengan masalah yang dihadapi dan muncul saat ini.

Di sinilah perlu membangun sebuah pemahaman baru. Pemahaman ajaran yang didasarkan realitas demi pemecahan masalah. Tentu saja pemahaman baru tidak selamanya harus semuanya baru. Islam mempunyai tradisi yang kaya, sebuah kanzun makhâfi, yang tidak pernah kering untuk kembali dan diwujudkan seraya melakukan kritik dalam rentang zaman yang melaju dengan segala perubahannya.

Tulisan ini selanjutnya akan menguak tradisi tasawuf dalam Islam sebagai sebuah "kanzun makhâfi." Kalau tasawuf kemudian berhenti hanya sebagai sebuah "harta

2 Berbagai fenomena dapat diamati. Islam kini-meskipun terlalu simplisistis—menjadi komoditas, sebagai barang dagangan yang dijual. Semuanya berubah dan tunduk pada kepentingan pasar dan komoditi. Pendidikan Islam pun mengikuti arus pasar untuk meraih keuntungan atas nama kualitas. Padahal kualitas tidak kunjung didapat. Pendidikan lalu hanya menghasilkan orangorang yang siap dipekerjakan, atau pendidikan membuat orang pandai untuk mengambil dan memanfaatkan peluang untuk kepentingannya sendiri.

3 Machasin, Islam Teologi Aplikatif, (Yogyakarta: Pustaka Alif, 2003), hal. 75. 
yang terpendam," maka kemanfaatannya tidak dapat dirasakan. Oleh karena itu, tulisan ini akan berusaha mengangkat tasawuf ke permukaan (bukan menurunkan dari atas) dan memanfaatkannya untuk menjadi sebuah sarana transformasi diri menuju pancaran Ilâhiyah yang transenden dalam konteks berbangsa Indonesia, yang mayoritasnya adalah umat Muslim. Agar kajian ini lebih terfokus, penulis membatasi pada satu tokoh tasawuf, al-Ghazâli. Sedangkan aspek tasawuf yang menjadi titik tekan adalah aspek etika tasawuf atau moral.

\section{B. Al-Ghâzali dan Tasawuf}

Sebelum dibahas lebih jauh lagi, di sini penulis perlu memberi alasan mengapa al-Ghazali dan tasawuf yang dijadikan pokok bahasan? Lebih jauh pertanyaannya, mengapa tasawuf diunggulkan sebagai sebuah alternatif atas kemelut bangsa ini, bukan tradisi Islam lain, seperti tradisi fiqh, kalam atau filsafat yang tidak kalah gandrung wacananya dalam studi Islam? Apa kaitan tasawuf dengan keadaan bangsa dan pemerintah Indonesia?

Pertama, mengapa tasawuf? Selain ilmu kalam, filsafat, fiqh/ushul fiqh, tasawuf adalah bagian dari bidang pemikiran Islam. ${ }^{4}$ Kata "pemikiran" di sini menunjuk pada upaya pemahaman terhadap ajaran Islam.

Ajaran dan formula Nabi Muhammad Saw yang sederhana dan telah dicontohkan pada masanya, seiring dengan perkembangan sosial budaya yang terjadi pada masa al-khulâfâ al-râsyidûn, kerajaan Ummayah, Abbasiyah, seiring itu pula terjadi perubahan dan perkembangan. Perkembangan ini tidak bisa dielakan lagi karena tuntutan perubahan zaman, perbedaan geografis (yang kemudian muncul aliran Hijaz, Kufah, Iraq, dan Persia) serta latar belakang sejarah sosial-budaya bangsabangsa yang baru masuk Islam. ${ }^{5}$

Seiring perkembangan itu, munculah ilmu-ilmu keislaman yang berpengaruh pada masanya hingga sekarang. Perkembangan itu dapat dilihat dalam dua peta atau tataran. ${ }^{6}$ Pertama, muncul ilmu tafsir, ilmu hadits, dan ilmu bahasa. Kedua,

4 Lihat misalnya dalam Nurcholis Madjid, Islam Doktrin dan Peradaban, (Jakarta: Paramadina, 1992). Lihat juga dalam M. Amin Abdullah, Islamic Studies di Perguruan Tinggi: Pendekatan IntegratifInterkonektif, (Yogyakarta: Pustaka Pelajar, 2006), hal. 302.

5 Lihat Majid Fakhry, Sejarab Filsafat Islam, terj. Mulyadi Kartanegara, Jakarta: Pustaka Jaya, 1987), hal. 31-49.

6 M. Amin Abdullah, "Tasawuf: Dimensi Batin Agama," dalam Studi Agama: Normativitas atau Historisitas, (Yogyakarta: Pustaka Pelajar, 1996), hal. 150-152. 
muncul dan berkembang ilmu kalam (teologi) dengan tokoh-tokoh yang pendukungnya seperti Wasil ibn 'Ata', Abu Hasan al-Asy'ari, al-Maturidi dengan aliran pemikiran kalam seperti Mu'tazilah, Asy'ariyah, dan al-Maturidiyah. Pembahasaan mengenai sifat dua puluh, Jabariyah dan Qodariyah, sifat wâjib, jâir, dan mumkin al-wnjûd bermunculan serta dikaji secara detail. Setelah umat Islam bertemu dan terjadi kontak dengan ajaran-ajaran dan kebudayaan-kebudayaan Kristen, Yahudi, Manikea dan Yunani, mereka pun bersusah payah melakukan rumusan kembali terhadap ajaran Islam yang dapat menjawab tantangan dari luar. Beragam ilmu bantu seperti logika dan filsafat mulai dimanfaatkan untuk merumuskan kembali ajaran-ajaran yang semula sederhana tadi untuk mempertahankan diri serta menandingi ajaran-ajaran dari luar.

Masih dalam tataran kedua, muncul ilmu figh dengan berbagai tokohnya seperti Imam Syafi'i, Hanbali, Maliki, dan Hanafi. Dalam ilmu ini, berpuluh-puluh, bahkan beratus-ratus buku dan jilid ditulis oleh para ulama. Persoalan rukun Islam yang awalnya sederhana mulai diperluas dan diklasifikasikan menjadi bab wudhu, tayamum, mandi, shalat, haji, zakat, dan muamalah lengkap dengan argumentasi ayat al-Qur'an dan Hadits Nabi disertai logika yang disusun oleh para ulama Imam Madzhab masing-masing. Oleh karena pembahasaannya dan cara berpikir yang terlalu terfokus pada persoalan penyesuaian amal perbuatan dengan aturan hukum fiqh dalam madzhab tertentu, penghayatan keagamaan menjadi sangat formalistik dan legalistik yang berhenti pada aturan-aturan lahiriah.

Merasa tidak puas dengan corak keagamaan yang terlalu formal dan lahiriah yang diusung oleh ilmu kalam dan ilmu figh, maka muncullah tasawuf yang lebih menekankan aspek bathiniyah atau aspek substansi dalam beragama.

Terlepas dari perdebatan mengenai asal mula timbulnya aliran sufisme, ${ }^{7}$ tasawuf dan sufisme ini mampu menarik golongan terbesar umat Islam, bahkan dalam informasi sejarah, Islam bisa masuk ke Indonesia berkat dakwah-dakwah para imam

7 Mengenai teori asal mula munculnya aliran sufisme, Harun Nasution mengajukan paling tidak ada lima teori; (1) pengaruh ajaran Kristen tentang paham menjauhi dunia dan mengasingkan diri hidup di biara-biara; (2) pengaruh filsafat mistik Phytagoras tentang pandangan roh manusia yang bersifat kekal dan hidup dunia sebagai orang asing; (3) pengaruh filsafat emanasi Plotinus tentang pendapat bahwa wujud ini memancar dari zat Tuhan; (4) pengaruh ajaran Budha dengan paham Nirwananya; (5) pengaruh ajaran-ajaran Hinduisme yang mengajarkan untuk menjauhi dunia dan mendekat kepada Tuhan untuk mempersatukan Atman dengan Brahmana. Lihat Harun Nasution, Falsafah dan Mistisisme dalam Islam, (Jakarta: Bulan Bintang, 1999), p. 55-56. 
sufi. ${ }^{8}$ Menyebarnya gerakan tarikat, baik yang ortodok maupun yang heterodok adalah bukti bahwa gerakan tasawuf mampu menarik banyak orang. Para tokoh sufi tidak puas dengan pemahaman keagamaan yang bersifat intelektualis dalam diri teolog dan filsuf, serta pemahaman keagamaan yang terlalu bersifat formalistik-legalistik.

Berbagai istilah-istilah dalam al-Qur'an yang sangat kaya dengan makna bathiniyah dikumpulkan oleh tokoh-tokoh sufi seperti Taubât, Syukr, Shabr, Tawakal, Ridhâ, Ikblâs, Wara', Qanâ'ah, Raja', Hubb, dan Khauf.' Istilah-istilah tersebut kemudian menjadi indikasi seseorang mampu menjadi seorang sufi, yang kemudian mampu mendekatkan diri pada Allah (Taqârub illa Allâh).

Sayangnya, tasawuf kemudian hanya berhenti pada sikap-sikap individual tanpa memikirkan implikasi dari berbagai ajaran dan sikap-sikap seperti zubld, 'uそlah, atau qanâ'ah terhadap problem sosial. Lebih parah lagi adalah tasawuf kemudian hanya terhenti sampai pada persaingan-persaingan antara kelompok tarikat untuk mendapatkan pengikut. Kalau sudah begitu, tasawuf tak ubahnya lagi dengan dua model pemikiran Islam dalam bidang kalam dan fiqh. Padahal ibarat sebuah harta karun terpendam yang selalu diburu atau ibarat sebuah magnit yang tidak tampak di permukaan, tasawuf mempunyai daya kekuatan yang luar biasa. Kekuatan atau potensi ini dapat digunakan untuk apa saja. Dalam kehidupan modern yang serba materi, tasawuf sebenarnya bisa dikembangkan ke arah yang membangun dan bermakna menuju kehidupan pribadi serta sosial yang lebih baik. Sampai di sini penulis mengajukan untuk kembali memunculkan tasawuf dan menjadikan tawaran atas kemelut sosial bangsa atas dasar sifat dasar tasawuf yang menekankan aspek batin dengan konsep i $\underline{i} s a ̂ n$ dalam praktik kehidupan sosial dan keagamaan. ${ }^{10}$

Kedua, mengapa al-Ghazali ${ }^{11}$ ? Sesungguhnya alasan ini sangat subjektif. Namun, subjektivitas pemilihan tokoh ini bukannya tanpa alasan. Paling tidak ada dua alasan yang dapat diajukkan ketika dikaitkan dengan masalah dalam tulisan ini.

8 Lihat misalnya hasil penelitian Azyumardi Azra, Jaringan Ulama Timur Tengah dan Kepulauan Nusantara Abad XVII dan XVIII, (Bandung: Mizan, 1999).

9 Harun Nasution, Falsafah dan Mistisisme dalam Islam, (Jakarta: Bulan Bintang, 1999), hal. 62-67.

10 Mungkin ini telah dipraktikan oleh Ormas Islam seperti Muhammadiyah yang menerjemahkan tasawuf dalam tafsiran etika sosial yang teraktualisasikan dalam pengembangan pendidikan, mendirikan sekolah-sekolah, rumah sakit, dan panti-panti. Begitu juga dengan NU, yang memang kental dengan ajaran sufinya telah pula melakukan aktualisasi tasawuf dalam berbagai lembaga-lembaga sosial. M Amin Abdullah (1996), “Tasawuf: Dimensi Batin Agama,”.., hal. 156.

11 Nama lengkap al-Ghazali adalah Abu Hamid Muhammad bin Muhammad bin Ahmad al-Ghazali. Dilahirkan di desa Ghuzala daerah Thus, salah satu kota di Khurasan, Persia pada tahun 450 H/1085 M. Abdul Hadi Abu Raidah, Tarikh al-Falsafah al-Islâm, (Kairo: Lajnah Ta'lif wa al-Tansyir, 1938), hal. 199. 


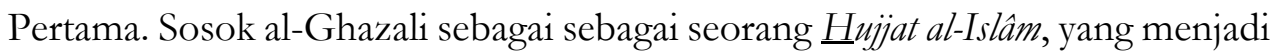
salah satu panutan umat Islam di seantero dunia tidak dapat dipungkiri, bahkan sebagian besar muslim Indonesia tentu mengenali dan menjadikan al-Ghazali sebagai panutan. Apalagi sebagian besar Muslim Indonesia penganut Asy'ari dalam teologi atau terkenal dengan apa yang sisebut dengan Abl al-Sunnab wa al-Jamấah (Sunni/ Aswaja)—meskipun masih terjadi silang pendapat dan perebutan makna Sunni ini dalam pelbagai kelompok Islam di Indonesia sendiri. ${ }^{12}$

Kharisma al-Ghazali sebagai seorang tokoh layaknya sebuah magnit yang menarik dan membuat orang terpesona akan menjadi sebuah kekuatan dan potensi yang konstruktif jika dilakukan rekonstruksi atau reformulasi kembali pemikiran tasawufnya untuk membangun tatanan sosial masyarakat Indonesia yang mayoritasnya Muslim ini.

Kedua. Pemilihan al-Ghazali sebagai kajian dalam tulisan ini berkaitan dengan kehidupannya yang relatif identik dengan situasi sosial, umat, dan pemerintahan Indonesia yang carut marut ini. Di sini kontekstualisasi kondisi sosio-historis al-Ghazali ke dalam kondisi sekarang dan saat ini dilakukan lewat pendekatan hermeneutik.

Sebelum al-Ghazali lahir, masyarakat sudah mengalami kemunduran dan kelemahan. Di bidang sosial politik, kerajaan Abbasiyah yang merupakan lambang bagi persatuan umat telah sedemikian rapuh. Kelemahan ini, menurut Montgomery Watt disebabkan oleh tiga hal: 1) Lemahnya sistem kontrol dan kendali sesudah makin luasnya wilayah kerajaan, 2) Makin meningkatnya ketergantungan kerajaan pada tentara bayaran dan, 3) Sistem manajemen keuangan yang tidak efisien. ${ }^{13}$ Di bidang lain, seperti bidang intelektual, moral dan agama secara umum juga mengalami kemerosotan dan kemunduran. Dinasti Abbasiyah mulai rapuh dan melemah karena kuatnya daerah-daerah bagian, seperti mendominasinya dinasti Buwaihi atas Baghdad, sebelum Abbasiyah akhirnya hancur oleh gempuran serangan kekuasaan Hulagu Khan. Berkuasanya Bani Saljuk yang menggantikan Dinasti Buwaihi pada pertengahan abad XI Masehi juga tidak mampu mengembalikan kekuatan politik yang cukup berarti karena hanya mampu bertahan selama tiga puluh tahun. ${ }^{14}$

Ketika dinasti Saljuk sudah mundur dan lemahnya kekuasaan politik serta goyahnya stabilitas nasional, al-Ghazali lahir dan hidup. Pada masa kehidupannya,

12 Lihat Said Aqil Siroj, Tasamuf Sebagai Kritik Sosial: Mengedepankan Islam sebagai Inspirasi, Bukan Aspirasi, (Bandung: Mizan, 2006).

13 Watt, W Montgomery, Kejayaan Islam, (Yogyakarta: Tiara Wacana, 1990), hal. 165-166

14 Ibid., hal. 248-249 
keadaan umat telah mengalami kemunduran dalam berbagai aspeknya. Di bidang pendidikan dan kejiwaan, umat mengalami kemiskinan intelektual, spiritual, dan moral. Disorientasi kehidupan telah melanda umat, sehingga tarikan-tarikan segisegi keduniaan dalam berbagai aspek kehidupan telah banyak mengalahkan aspek keakhiratan. Bidang agama yang seharusnya menuntut pengamalan dan penghayatan secara intens, tidak jarang pula dimanfaatkan orang untuk mencari popularitas, pangkat, dan jabatan kekuasaan. Dalam bidang budaya dan ilmu, meskipun ada sedikit kemajuan, tetapi tidak pula dibarengi dengan kemajuan spiritual, moral, dan agama. Sebab motivasi orang yang mengembangkan ilmu maupun budaya pada umumnya hanya untuk mencari keuntungan duniawi dan melalaikan aspek akhirat. Hal ini diakui al-Ghazali dalam bukunya yang berjudul al-Munqidz min al-Dhalâl. ${ }^{15}$ Dalam bidang pemikiran juga tidak luput dari permasalahan, sehubungan dengan terjadinya polarisasi dan pluralisasi paham dari berbagai golongan, dan masing-masing mengklaim diri atau kelompoknya paling benar.

Menghadapi dunia Islam saat itu yang dipenuhi oleh fragmentasi sosial politik dan pemikiran-pemikiran yang tidak terkontrol, serta dibarengi dengan merebaknya penyempitan paham, dan kurangnya sikap tasâmub (toleransi) di antar sesama Muslim, al-Ghazali dengan sikap kritis serta keberaniannya mengambil keputusan untuk menentukan pilihan dan mengambil keputusan untuk menentukan pilihannya untuk menempuh jalan sufi. Dia menempuh jalan sufi sebagai fondasi teologisnya. Sikap inilah yang kemudian terekam dalam karya monumentalnya $I \underline{h} y \hat{a}$ Ulúmuddin. Itulah sebabnya dalam bukunya itu sarat dengan pengajaran dan muatan-muatan moral dan spiritual sebagai usaha mempertahankan kebenaran pandangan dan realitas melalui seruan untuk kembali kepada Allah Swt.

Keadaan obyektif terhadap setting sosial-budaya atau konteks masa al-Ghazali dapat memberikan gambaran mengapa al-Ghazali menjatuhkan pilihannya pada tasawuf sebagai alternatif pemecahan masalah atas problem sosial-agama yang melanda umat Muslim kala itu. Jika dikontekstualisasikan dengan keadaan sekarang di sini, dalam konteks bangsa Indonesia, sesungguhnya tidak jauh berbeda keadaannya. Bisakah tasawuf al-Ghazali dijadikan jalan pemecahan masalah? Tentu bukan maksud untuk menyederhanakan masalah jika jawaban penulis adalah "ya." Argumen yang dapat diajukan adalah jika hati nurani tidak lagi berbicara, apa lagi

15 Al-Ghazali, al-Munqidz min al-Dhalâl, (Beirut: Al-Sya'biyah, tt), hal. 71. 
yang kita andalkan untuk menjadi manusia. Masalah hati nurani adalah masalah batini, masalah batini adalah masalah tasawuf. Salah satu karakteristik tasawuf adalah peningkatan moralitas atau etika, baik moralitas individu maupun sosial. ${ }^{16}$

\section{Etika Tasawuf al-Ghazali}

Penulis lebih memilih menggunakan kata etika dari pada akhlak, meskipun kata yang terakhir ini lebih banyak dikenal di kalangan Muslim sendiri. Etika lebih dikenal dalam tradisi filsafat ${ }^{17}$ dari pada dalam khazanah tasawuf. Dalam khazanah Islam atau lebih khususnya tasawuf lebih sering dan lebih dikenal dengan akhlak. Etika juga sering disamakan dengan moral. Keduanya menunjuk pada arti yang sama, yakni nilai-nilai atau norma-norma yang berlaku dalam sebuah masyarakat. Hanya saja asal katanya yang berbeda, jika etika berasal dari bahasa Yunani Kuno, sedangkan moral berasal dari bahasa Latin. ${ }^{18}$

Sedangkan akhlak lebih dimaksudkan sebagai suatu produk jadi yang bersifat normatif-mengikat yang harus diterapkan oleh seorang Muslim dalam kehidupan sehari-hari. Akhlak adalah seperangkat tata nilai keagamaan yang harus diwujudkan dalam kehidupan sehari-hari, tanpa perlu mempertanyakan terlebih dahulu secara kritis. ${ }^{19}$ Etika selalu dilalui dengan proses permenungan, baik itu melalui penalaran rasional ('akaliyah) maupun secara intuitif. ${ }^{20}$

16 M. Amin Syukur, dan Masyharuddin, Intelektualisme Tasawnf: Studi Intelektualisme Tasawnf al-Ghazali, (Yogyakarta: Pustaka Pelajar, 2002), hal. 183.

17 M. Amin Abdullah, Falsafah Kalam di Era Postmodernisme, (Yogyakarta: Pustaka Pelajar, 2004), hal. 146.

18 K. Bertens, Etika, (Jakarta: Gramedia Pustaka Utama, 2001), hal. 4-7.

19 M Amin Abdullah, Falsafab Kalam..., hal. 147.

20 Dalam epistemologi Barat, intuisi belum mendapat tempat sebagai metode untuk mendapatkan pengetahuan, sedangkan dalam epistemologi Islam, selain pengetahuan empiris dan rasional, pengetahuan intuitif diakui juga mampu untuk mendapatkan pengetahuan sejati (ma'rifât). Lihat Mulyadhi Kartanegara, Menyibak Tirai Kejabilan: Pengantar Epistemologi Islam, (Bandung: Mizan, 2003) hal. 1829. Pengetahuan intutif secara epistemologi berasasal dari intuisi atau qalb (hati). Ia diperoleh melalui pengamatan langsung, tetapi tidak pada obyek lahir melainkan terhadap hakikat obyek tersebut. Pengetahuan intuitif sesungguhnya tetap termuat dalam intelektualitas manusia pada umumnya, tetapi agak dilawankan dengan pengetahuan akal (rasional), sejauh hal itu menekankan sistematika dan kekuatan metodis. Baik akal maupun intuisi dilokalisasikan dalam kedua belah otak manusia. Belahan otak kanan memiliki kecenderungan dan kepekaan rasa, aktifitas spontan dan feeling yang merupakan sumber intuisi. Sementara otak kiri memeiliki kecenderungan dan kepekaan logis, matematis sebagai basis rasio atau akal. Masing-masing selalu dalam keadaan interaktif. Lebih jauh lihat Anton Bakker dan Achmad Charis Zubair, Metodologi Penelitian Filsafat, (Yogyakarta: Kanisius, 1990), hal. 25. 
Sejalan dengan ide dasar tasawuf yang menekankan aspek batin dan substansi dalam perbuatan, etika tasawuf adalah bukan saja etika atau urusan moralitas yang selalu menekankan aspek lahir, tetapi melampaui yang lahir menuju maksud terdalam sebuah perilaku atau tindakan. Jika kemudian etika dimaknai sebagai sebuah permenungan akan baik dan buruk yang melahirkan moralitas dalam perilaku, maka etika tasawuf mempertimbangkan antara yang baik dan buruk itu dengan kaca mata batin dan hakikat. Etika tasawuf tidak menghiraukan aspek materi, karena bagi seorang sufi materi tidak penting dan bukan tujuan. Tujuan dari segala perbuatan, bagi seorang sufi adalah taqârub illa Allâh bahkan kasyf, bertemu dengan Allah Swt.

Sebagai seorang sufi, al-Ghazali pun mempunyai teori tentang etika sebagai bagian dari disiplin tasawufnya. Banyak ahli mengelompokkan dia ke dalam tokoh sufi, tetapi juga banyak ahli yang menggolongkan ke dalam tokoh filsafat. Hal ini bukan tanpa alasan. Dari beberapa buku yang dia tulis memang menunjukkan ketertarikannya akan kedua bidang tersebut. Jika melihat bukunya yang berjudul Maqâshid al-Falâsifah atau Tahâfut al-Falâsifah, atau melalui Mi'yâr al'Ilmnya, akan dapat disimpulkan bahwa al-Ghazali adalah seorang filsuf sejati. Hanya bila melihat karyanya seperti dalam master piecenya Ibyâ al-Ulûm al-Dîn, atau Kitab al-Arbâ'in dan al-Munqidz, min al-Dhalâl, akan dapat disimpulkan dia adalah seorang mistikus atau sufi yang sejati pula. ${ }^{21}$ Sebaiknya pendekatan keduanya terhadap pikiran al-Ghazali itu dipadukan sehingga sosok pemikirannya akan terlihat utuh dan tidak berat sebelah. Atas dasar itu, kajian etika tasawuf al-Ghazali akan menjadi lebih lengkap jika dua jalan pemikirannya dilihat.

Di sini penulis menggunakan dua term tasawuf yang sangat dikenal, yakni tasawuf akblâqi $i^{22}$ dan tasawuf falsafi. ${ }^{23}$ Kedua istilah ini akan penulis gunakan secara lebih longgar untuk lebih mudah memahami corak pemikiran etika tasawuf al-Ghazâli, sehingga dapat diamalkan dalam kehidupan nyata. Selain kedua istilah tasawuf itu, ada istilah tasawuf 'amâli. ${ }^{24}$ Tasawuf akhlâqi dan tasawuf falsafi penulis artikan sebagai proses permenungan tentang sebuah etika tentang sesuatu yang baik dan yang buruk. Keduanya lalu menghasilkan tasawuf 'amâli (praktik), yakni permenungan yang menghasilkan tindak perbuatan. Tasawuf akhlaki lebih

21 M Amin Abdullah, Studi Agama...., hal. 270.

22 Tasawuf akblâki adalah ajaran tasawuf yang membahas tentang kesempurnaan dan kesucian jiwa yang diformulasikan pada pengaturan sikap mental dan pendisiplinan tingkah laku yang ketat guna mencapai kebahagian yang optimal. M. Amin Syukur, Intelektualisme Tasawnf..., hal. 45.

23 Tasawuf falsafi adalah tasawuf yang ajaran-ajarannya memadukan antara visi intuitif dan visi rasional. Ibid., hal. 51.

24 Tasawuf amali yaitu tasawuf yang membahas tentang bagaimana cara mendekatkan diri kepada Allah. Tasawuf jenis lebih sering dimaknai dengan gerakan tarikat. Ibid., hal. 50. 
didasarkan pada ajaran agama. Sedangkan tasawuf falsafi banyak didasarkan pada penalaran rasional yang banyak dipengaruhi oleh pemikiran-pemikiran filsafat.

Dalam perspektif tasawuf akhlâqi, etika tasawuf al-Ghazali dapat dilihat dalam konsep zuh. Dalam kitab al-Arbâ'in, ${ }^{25}$ al-Ghazali mendefinisikan zuhㅓ sebagai berpalingnya seseorang menjauhi urusan dunia, meskipun dia mampu memperolehnya. al-Ghazali membagi tingkatan zubd dari segi tingkatan motivasi yang mendorongnya kepada tiga tingkatan:

1. Zubd yang didorong oleh rasa takut terhadap api neraka. Zubd dalam tingkatan ini adalah zuhd-nya orang-orang pengecut.

2. Zubd yang didorong untuk mencari kenikmatan hidup di akhirat. Zubd dalam tingkatan ini adalah zuhd orang-orang yang berpengharapan, yang hubungannya dengan Allah diikat oleh ikatan pengharapan dan cinta, bukan ikatan disebabkan rasa takut.

3. Zubd yang didorong oleh keinginan untuk melepaskan diri dari memperhatikan apa selain Allah dalam rangka membersihkan diri dari padanya dan menganggap remeh terhadap apa yang selain Allah. Zuhd dalam tingkatan ini adalah zubd para 'arifin, orang-orang yang mencapai derajat ma'rifät. ${ }^{26}$

Menurut al-Ghazali, ma'rifât harus terlebih dahulu melalui mababbah. Melalui mahabbah timbul ma'rifât. Untuk memperkuat ma'rifât tentang Allah dalam hati, dibutuhkan pembersihan diri dari segela kesibukan dunia. ${ }^{27}$

Dalam perspektif "tasawuf falsafi" pemikiran etika tasawuf al-Ghazali dapat dilihat dari hukum kausalitas atau sebab akibat. ${ }^{28}$ Pemikiran tentang hukum kausalitas ini melahirkan corak pemikiran etika yang cenderung pada pola teleologis. ${ }^{29}$ Corak

25 Sebagaimana yang dikutip oleh M. Amin Abdulah, Intelektualisme Tasaruf..., hal. 278.

26 Ibid., hal. 278-279.

27 Ibid., hal. 278.

28 Ibid., hal. 271.

29 Teleologis berasal dari kata telos (tujuan) dan logos (ilmu). Dalam kajian filsafat, teleologis adalah suatu pengetahuan yang digunakan sebagai argumen tentang wujud Tuhan yang mengatakan bahwa segala ciptaan mempunyai tujuan dalam evolusinya. Namun, alam sendiri tidak dapat menentukan tujuan itu, sebab yang menentukan harus yang mengatasi alam yaitu Tuhan. Lihat Harun Nasution, Filsafat Agama, (Jakarta: Bulan Bintang, 1979), hal. 60-62. Lorens Bagus memberikan pengertian teleologis sebagai studi tentang gejala-gejala yang memperlihatkan keteraturan, rancangan, tujuan, akhir, maksud, kecendrungan, sasaran, arah dan bagaimana hal-hal ini dicapai dalam suatu proses perkembangan. Studi ini mencapai doktrin bahwa tujuan, sebab akhir/final atau maksud harus diketengahkan sebagai prinsip-prinsip penjelasan. Istilah ini diperkenalkan pertama kali oleh Christian Wolff. Lorens Bagus, Kamus Filsafat, (Jakarta: PT. Gramedia Pustaka Utama, 2000), hal. 1085. 
pemikiran etika ini akhirnya melahirkan teori etika teleologis. Etika ini adalah sebuah cabang dari etika normatif yang menyatakan bahwa baik-buruknya sebuah tindakan dari sudut pandang etika ditentukan oleh suatu tujuan tertentu. ${ }^{30}$

Pemikiran ini cenderung terhadap corak pemikiran Aristoteles, yang kemudian diikuti para filsof Muslim seperti Ibnu Sina, al-Farabi dan Ibnu Miskawih yang menimbang nilai kebaikan atau keburukan suatu perbuatan dikaitkan dengan akibatnya dalam hal meningkatkan atau menghalangi kebahagian (al-sa'âdab). ${ }^{31}$

Dalam Ihyâ al-Ulûmuddin, teori etika teleologis ini sangat tampak diajukan oleh al-Ghazali. Menurut al-Ghazali tujuan luhur dari manusia adalah kebahagian akhirat. Oleh karena itu, suatu amal dipandang baik bila amal itu menghasilkan pengaruh pada jiwa yang membuatnya mengarah ke tujuan itu, demikian juga sebaliknya. ${ }^{32} \mathrm{Jadi}$, tolok ukur baik atau buruknya sebuah perbuatan dapat dibedakan karena adanya pengaruh yang ditimbulkan terhadap jiwa pelakunya, apakah semakin dekat dengan Tuhan, atau menjauhinya. ${ }^{33}$

Sesungguhnya teori etika ini dapat dipertemukan dengan konsep zuud di atas. Seorang yang tujuan hidupnya adalah hanya Allah semata, maka dunia materi lainnya bukanlah menjadi tujuan hidupnya. Hal ini sama dengan konsep zuud dalam tingkat yang ketiga, yakni zuhd para 'arifin, yang membersihkan diri dari selain Allah. Selain Allah bagi seorang zâhid (orang yang zubd) adalah semua hal yang tidak menjadi tujuan untuk mendapatkan kebahagian akhirat. Oleh karena tidak mendatangkan kebahagian akhirat, harus ditinggalkan.

Pemikiran etika al-Ghazali yang lain dalam kaitannya dengan tasawuf falsafi adalah pandangan tentang sumber-sumber keutamaan (ummahât al-fadhâii). Maksud keutamaan adalah berfungsinya daya-daya yang dimiliki manusia sesuai dengan tuntutan kesempurnaan manusia. ${ }^{34}$ Tidak berfungsinya daya-daya tersebut akan menyebabkan keburukan-keburukan (al-razâii)..$^{35}$ Dalam Mizân al-'Amal, al-Ghazali menuntut adanya keseimbangan ( $a l$-'adl) antara daya-daya tersebut. Al-Ghazali

30 Ibid, hal. 1087. Bertens menyebut etika ini juga dengan sistem etika konsekuensialistis, yakni sebuah sistem etika yang berpandangan bahwa baik tidaknya perbuatan dianggap tergantung pada konsekuensinya, pada akibatnya, yang semuanya berorientasi pada tujuan perbuatan. K Bertens, Etika..., hal. 254 .

31 Abu al-Quasem, Etika Al-Ghazali, terj. Muhyiddin, (Bandung: Pustaka, 1988), hal. 14.

32 Al-Ghazâli, Ibyâ al-Ulûmuddîn, jilid IV, (Beirut: Dar al-Filler, tt), hal. 138.

33 Ibid, jilid II, hal. 9-11.

34 Murad Wahbah, al-Mu'jam al-Falsafi, (Kairo: al-Tsaqofah al-Jadidah, 1971), hal. 161.

35 Ibid., hal.103. 
mengemukakan empat keutamaan tertinggi, yaitu: al-hikmah sebagai keutamaan akal, al-syajâ'ah sebagai keutamaan daya al-ghadb, al-iffah sebagai keutamaan daya al-syahwah, dan al'adalah sebagai keutamaan daya atau faktor penyeimbang. Al-'adl adalah keseimbangan dari dua segi, yakni dari penempatan masing-masing keutamaan itu di antara kedua keburukan dan dari segi penempatan akal sebagai alat kontrol. ${ }^{36}$ Misalnya al-ghadb dan al-syahwah adalah dua kecendrungan yang inheren di dalam daya pendorong (al-ba'its) atau kehendak (al-irâdab). Al-ghadb akan menimbulkan keberanian untuk melakukan apa saja untuk menentang sesuatu yang merugikannya. Sebaliknya, dengan kecendrungan al-Syahwah, seseorang akan berusaha memiliki sesuatu yang menguntungkannya. Tanpa ada daya yang lebih tinggi, al-ghadb akan menimbulkan kebuasan, sedangkan al-syahwah akan menimbulkan keserakahan. Oleh karena itu perlu penyeimbang (al-'adl), yakni akal. Akal akan menangkap al-bikmah yang berfungsi menempatkan sesuatu secara proposional. ${ }^{37}$

Pandangan keseimbangan ini (al-tawassut) dapat dirujuk kepada Aristoteles. Hanya saja pandangan tersebut lebih dahulu dijumpai oleh para filosof sebelum alGhazali seperti Ibnu Sina, al-Farabi, dan Ibnu Miskawih. ${ }^{38}$

\section{E. Penutup}

Substansi kehidupan tasawuf adalah kesederhanaan. Tasawuf mengajak manusia melepaskan diri, sehingga manusia menjadi benar-benar merdeka dan tidak menghambakan diri kecuali kepada Allah Swt. Tasawuf mengajak kepada persamaan, saling membantu dan mempererat persaudaraan. Tasawuf membentuk dan membina manusia yang sempurna. ${ }^{39}$

Konsep tentang zubd, pemikiran tentang kebahagian akhirat, dan keseimbangan hidup tersimpulkan pada sikap hidup yang sederhana Kesederhanaan akan menghilangkan keserakahan. Sifat serakah disebabkan dominasi daya alSyahwah. Apapun harus dimiliki untuk memenuhi kesenangan meskipun dengan cara yang tidak baik dan merugikan orang lain. Korupsi diantaranya disebabkan dominasi al-Syahwah. Budaya KKN dan tidak adanya transparansi dalam

36 Al-Ghazali, Mîâan al-Amal, (Mesir: Dar al-Ma'arif, 1964), hal. 272.

37 M. Amin Syukur, Intelektualisme Tasawnf..., hal. 186.

38 Muhammad Yusuf Musa (1963), Falsafah al-Akhlâk fi al-Islâm, Kairo: Muassah al-Khatji, p. 203, 205.

39 Lihat Muhammad Zaki Mubarak, Tasawuf Salafi: Menyucikan Tasawuf dari Noda-Noda, (Jakarta: Hikmah, 2002), hal. 16. 
penyelenggaraan pemerintahan adalah indikasi menguatnya al-Syahwah. Selain itu setelah al-Syahwah, daya al-Ghadb juga semakin menguat. Persaingan yang tidak sehat, serangakaian tindak kekerasan, dan penyebaran fitnah. Semuanya dilakukan hanya demi menghilangkan ancaman terhadap keinginan nafsu yang ditimbulkan oleh daya al-Syahwah.

Al-Ghazali dulu ketika memilih jalan tasawuf dengan sikap hidup zubd disebabkan situasi yang memaksanya. Sebab baginya kesenangan dunia tidak akan memberikan kebahagiaan akhirat. Menurut penulis, bukan hanya kerugian di akhirat, di dunia juga akan mengalami kerugian. Keterbelakangan, kemiskinan, dan kebodohan adalah kerugian dunia yang disebabkan kecintaan terhadap dunia yang berlebihan. Begitu cintanya, semuanya ingin dimiliki dengan cara apapun. Akal dan hati nurani tidak lagi berfungsi. Oleh karenanya, tidak ada lagi keseimbangan. Ketidakseimbangan ini akhirnya akan menjadikan situasi yang kacau, tidak tentu arah, dan krisis yang berkepanjangan.

Zubd untuk masa kini dan dalam konteks good governance dapat diartikan dengan penegakan budaya trasparansi, fairness, accountability, responsibility, efektivitas dan efisiensi, dan visi strategis. Semuanya akan dapat dilakukan jika daya al-Syabwah dan al-Ghadb diminimalisir atau diimbangi dengan akal dan hati nurani. Sebagai sebuah konsep, etika tasawuf belum menjadi sebuah peraturan yang "siap pakai," namun, ruh etika ini perlu ditegakkan dalam berbagai perencanaan dan penyelenggaraan pemerintahan yang sehat. Zubd—dalam pengertiannya yang baruharus diketahui, bahkan kalau perlu diajarkan pada para calon-calon pemimpin di negeri ini. Tidak hanya itu, para konglomerat hingga buruh pabrik, tani, hingga yang menyandang predikat ulama sekalipun harus kembali disadarkan mengenai konsepsi zuhd ini. Bahkan akan lebih baik, zuhd—sekali lagi dalam pengertian yang baru—dimasukkan dalam kurikulum pendidikan kewargaan.

\section{DAFTAR PUSTAKA}

Abdullah, M. Amin. 1996. "Tasawuf : Dimensi Batin Agama," dalam Studi Agama: Normativitas atan Historisitas. Yogyakarta: Pustaka Pelajar. 2002. Antara al-Ghazali dan Kant: Filsafat Etika Islam. Bandung: Mizan. 2004. Falsafah Kalam di Era Postmodernisme. Yogyakarta: Pustaka Pelajar 2006. Islamic Studies di Perguruan Tinggi: Pendekatan IntegratifInterkonektif. Yogyakarta: Pustaka Pelajar. 
Al-Ghazali, Abu Hamid Muhammad ibn Muhammad ibn Muhammad. tt. Ibyâ alUlûmuddîn, jilid IV. Beirut: Dar al-Fikr. . 1328. Kitâb Al-Arba'în fí Ushûl al-Dinn. Mesir: Kurdistan al-'Ilmiyah. . T.t. al-Munqidz min al-Dhalâl. Beirut: Al-Sya’biyah. 1964. Mirân al-Amâl.Mesir:Dâral-Ma'ârif.

al-Quasem, Abu. 1988. Etika Al-Ghazali, terj. Muhyiddin. Bandung: Pustaka.

Azra, Azyumardi. 1999. Jaringan Ulama Timur Tengah dan Kepulauan Nusantara Abad XVII dan XVIII. Bandung: Mizan.

Bagus, Lorens. 2000. Kamus Filsafat. Jakarta: PT. Gramedia Pustaka Utama.

Bakker, Anton dan Achmad Charis Zubair. 1990. Metodologi Penelitian Filsafat. Yogyakarta: Kanisius.

Bertens, K. 2001. Etika. Jakarta: Gramedia Pustaka Utama.

Fakhry, Majid. 1987. A History of Islamic Philosophy, terj. Mulyadi Kartanegara Sejarah Filsafat Islam. Jakarta: Pustaka Jaya.

Hidayat, Komaruddin. 2007. "Menertawakan Kegetiran Hidup." Kompas, 21 April. Kartanegara, Mulyadhi. 2003. Menyibak Tirai Kejabilan: Pengantar Epistemologi Islam. Bandung: Mizan.

Machasin. 2003. Islam Teologi Aplikatif. Yogyakarta: Pustaka Alif

Madjid, Nurcholis. 1992. Islam Doktrin dan Peradaban. Jakarta: Paramadina.

Mubarak, Muhammad Zaki. 2002. Tasawnf Salafi: Menyucikan Tasawuf dari NodaNoda. Jakarta: Hikmah.

Musa, Muhammad Yusuf. 1963. Falsafah al-Akhlâk fi al-Islâm. Kairo: Muassasah alKhatji.

Nasution, Harun. 1979. Filsafat Agama. Jakarta: Bulan Bintang. 1999. Falsafah dan Mistisisme dalam Islam. Jakarta: Bulan Bintang.

Raidah, Abdul Hadi Abu. 1938. Tarikeh al-Falsafah al-Islâm. Kairo: Lajnah Ta’lif wa al-Tansyir.

Siroj, Said Aqil. 2006. Tasawuf Sebagai Kritik Sosial: Mengedepankan Islam sebagai Inspirasi, bukan Aspirasi. Bandung: Mizan. 
140 Millab Vol VII No 1 Agustus 2007

Syukur, M. Amin. 2002. Intelektualisme Tasawnf: Studi Intelektualisme Tasawnf alGhazali. Yogyakarta: Pustaka Pelajar

Wahbah, Murad. 1971. al-Mu'jam al-Falsafi. Kairo: al-Tsaqofah al-Jadidah.

Watt, W Montgomery. 1990. Kejayaan Islam. Yogyakarta: Tiara Wacana. 